\title{
Heantos-4, a natural plant extract used in the treatment of drug addiction, modulates T-type calcium channels and thalamocortical burst-firing
}

\author{
Stuart M. Cain', Soyon Ahn², Esperanza Garcia', Yiming Zhang', Zeina Waheed ${ }^{1}$, John R. Tyson' ${ }^{1}$, Yi Yang ${ }^{1}$,
} Tran Van Sung ${ }^{3}$, Anthony G. Phillips ${ }^{2}$ and Terrance P. Snutch ${ }^{1,2^{*}}$

\begin{abstract}
Heantos-4 is a refined combination of plant extracts currently approved to treat opiate addiction in Vietnam. In addition to its beneficial effects on withdrawal and prevention of relapse, reports of sedation during clinical treatment suggest that arousal networks in the brain may be recruited during Heantos administration. T-type calcium channels are implicated in the generation of sleep rhythms and in this study we examined whether a Heantos-4 extraction modulates T-type calcium channel currents generated by the Cav3.1, Cav3.2 and Ca3.3 subtypes. Utilizing whole-cell voltage clamp on exogenously expressed T-type calcium channels we find that Heantos inhibits Cav3.1 and Cav3.3 currents, while selectively potentiating Cav3.2 currents. We further examined the effects of Heantos-4 extract on low-threshold burst-firing in thalamic neurons which contribute to sleep oscillations. Using whole-cell current clamp in acute thalamic brain slices Heantos-4 suppressed rebound burst-firing in ventrobasal thalamocortical neurons, which express primarily Cav3.1 channels. Conversely, Heantos-4 had no significant effect on the burst-firing properties of thalamic reticular neurons, which express a mixed population of Cav3.2 and Cav3.3 channels. Examining Heantos-4 effects following oral administration in a model of absence epilepsy revealed the potential to exacerbate seizure activity. Together, the findings indicate that Heantos-4 has selective effects both on specific T-type calcium channel isoforms and distinct populations of thalamic neurons providing a putative mechanism underlying its effects on sedation and on the thalamocortical network.
\end{abstract}

Keywords: Burst firing, Thalamocortical, Thalamus, T-type, Calcium, Epilepsy, Addiction, Heantos-4

\section{Introduction}

Opiate dependence is estimated to affect 15 million people worldwide and opiate overdose is believed to result in approximately 69,000 mortalities per year [1]. While pharmacological therapies can be utilized during rehabilitation to reduce cravings (methodone, buprenorphine, suboxone), block of the rewarding effects (naltrexone) or lessen the negative symptoms of opioid withdrawal (antiemetics, sedatives, antidepressants), relapse rates remain

\footnotetext{
* Correspondence: snutch@msl.ubc.ca

${ }^{1}$ Michael Smith Laboratories and Djavad Mowafaghian Centre for Brain

Health, University of British Columbia, 219-2185 East Mall, Vancouver, BC V6T 1Z4, Canada

2Department of Psychiatry, University of British Columbia, Vancouver, Canada

Full list of author information is available at the end of the article
}

unfortunately high $[2,3]$. As such, there is a pressing need to discover and develop new therapies for the treatment of opiate addiction.

Heantos-4, which is the Greek term for "Plants" is a mixture of organic herbs developed in Vietnam and recently approved for the clinical alleviation of withdrawal symptoms in individuals dependent upon opiates [4]. Additionally, preliminary observations indicate that it aids in the reduction in relapse rates. A sedative effect of Heantos has been reported by patients during the first few days of treatment. Mechanistically, there is little current understanding of how Heantos mediates its effects on opioid withdrawal, relapse or sedation. Recent findings show that oral administration of Heantos-4 reduces drug-seeking behaviors in animal models of 
morphine addiction [5]. Further, microdialysis experiments have revealed that oral administration of Heantos in rats enhances dopamine efflux in the nucleus accumbens, providing a mechanistic correlate for its effects on addiction [5]. The current study examines the effects of Heantos on burst-firing of thalamic neurons due to the involvement of this brain region in non-REM sleep and the control of arousal [6].

Voltage-gated calcium channels are a class of membrane bound proteins that regulate the cellular entry of calcium ions upon depolarization [7]. T-type calcium channels $\left(\mathrm{Ca}_{\mathrm{V}} 3.1-\mathrm{Ca}_{\mathrm{V}} 3.3\right)$ are a sub-class of calcium channels that activate at more hyperpolarized membrane potentials than their High Voltage-Activated (HVA) counterparts $\left(\mathrm{Ca}_{V} 1.1-\mathrm{Ca}_{V} 1.4\right.$ and $\left.\mathrm{Ca}_{V} 2.1-\mathrm{Ca}_{\mathrm{V}} 2.3\right)$. As a result, T-type calcium channels open in response to smaller depolarizations than HVA calcium and sodium channels, endowing them with a unique the ability to modulate cellular excitability at near-resting membrane potentials [8]. Low-threshold burst-firing is a neuronal firing mode wherein a short duration of high frequency action potentials occur upon the crest of a "Low Threshold calcium Spike" (LTS) generated by T-type calcium currents $[8,9]$. Thalamic neurons display a well-characterized switch between burst- and tonic-firing depending on a combination of resting membrane potential and excitatory/inhibitory input [10]. While burst-firing occurs under normal conditions in the brain, in particular during sleep $[6,11]$ it is also associated with pathophysiological neuronal disorders, such as epilepsy [12-14].

In this study we examined whether Heantos-4 can directly modulate exogenously expressed T-type calcium channels ( $\left.\mathrm{Ca}_{\mathrm{v}} 3.1-\mathrm{Ca}_{\mathrm{v}} 3.3\right)$. Further, we correlated the effects observed for cloned channels with Heantosmediated modulation of ventrobasal (VB) and reticular thalamic nucleus (TRN) neurons in acute rat brain slices. Finally, we examined the effects of Heantos-4 oral administration on seizure activity in the absence epilepsy model, Genetic Absence Epilepsy Rats from Strasbourg (GAERS).

\section{Results}

\section{Heantos differentially modulates T-type calcium channel} subtypes

To assess whether Heantos directly alters T-type calcium channel currents, individual $\mathrm{Ca}_{\mathrm{v}} 3.1, \mathrm{Ca}_{\mathrm{v}} 3.2$ and $\mathrm{Ca}_{\mathrm{v}} 3.3$ isoforms were exogenously expressed in HEK293 cells. Following a $5 \mathrm{~min}$ application of Heantos-4 extracted in aCSF $\left(0.1 \mathrm{mg} / \mathrm{ml}\right.$, see Methods) $\mathrm{Ca}_{\mathrm{v}} 3.1$ and $\mathrm{Ca}_{\mathrm{v}} 3.3$ currents were significantly inhibited from the baseline $\left(\mathrm{Ca}_{\mathrm{v}} 3.1=\right.$ $-66.2 \pm 3.8 \%, P<0.001$ paired T-test; $\mathrm{Ca}_{\mathrm{v}} 3.3=-41.2 \pm 3.9 \%$ $P<0.05$ paired $\mathrm{T}$-test), whereas, $\mathrm{Ca}_{\mathrm{V}} 3.2$ currents were significantly potentiated $(35.0 \pm 14.9 \%, P<0.05$ paired T-test; Fig. 1). Furthermore, a concentration-dependent effect was observed with a lower concentration $(0.01 \mathrm{mg} / \mathrm{ml})$ across all three isoforms $(n=4)$, and a higher concentration $(1 \mathrm{mg} / \mathrm{ml})$ in the Cav 3.1 and Cav 3.3 channels (Fig. 1c).

Voltage-dependence effects of the Heantos-4 were also assessed by examining the current-voltage relationship at the $0.1 \mathrm{mg} / \mathrm{ml}$ concentration (Fig. 2). Following Heantos-4 application, a significant leftward shift in the activation curve was observed for both $\mathrm{Ca}_{\mathrm{V}} 3.1\left(\mathrm{~V}_{50}\right.$ control $=-46.2 \pm 2.4 \mathrm{mV}, \mathrm{V}_{50}$ Heantos $-4=-51.0 \pm 2.9 \mathrm{mV} ; P<0.05$ paired T-test) and $\mathrm{Ca}_{\mathrm{V}} 3.2\left(\mathrm{~V}_{50}\right.$ control $=33.3 \pm 1.1 \mathrm{mV}, \mathrm{V}_{50}$ Heantos- $4=42.0 \pm 1.9 \mathrm{mV} ; P<0.05$ paired T-test), but not for $\mathrm{Ca}_{\mathrm{v}}$ 3.3. $\left(\mathrm{V}_{50}\right.$ control $=38.2 \pm 1.8 \mathrm{mV}, \mathrm{V}_{50}$ Heantos $-4=$ $37.4 \pm .9 \mathrm{mV}$ ) (Fig. 2c). In addition, the voltage-dependent kinetics of $\mathrm{Ca}_{\mathrm{v}} 3.2$ currents were also altered by Heantos- 4 application with the tau of activation increased between $-45 \mathrm{mV}$ and $-20 \mathrm{mV}$ and the tau of inactivation increased between $-40 \mathrm{mV}$ and $0 \mathrm{mV}$ (Fig. $2 \mathrm{~d}$ and e). The tau of inactivation for $\mathrm{Ca}_{\mathrm{V}} 3.3$ was significantly smaller (faster inactivating) between $-35 \mathrm{mV}$ and $10 \mathrm{mV}$ following Heantos-4 application (Fig. 2e).

\section{Heantos-4 inhibits burst-firing in VB neurons}

Given that Heantos-4 inhibited $\mathrm{Ca}_{\mathrm{v}} 3.1$ and $\mathrm{Ca}_{\mathrm{v}} 3.3$ currents but potentiated $\mathrm{Ca}_{\mathrm{V}} 3.2$ currents, we sought to evaluate its effects in a native system wherein these T-type isoforms are differentially expressed. VB neurons are glutamatergic, sensory thalamocortical neurons that primarily express the $\mathrm{Ca}_{V} 3.1$ channel [15-17] and we hypothesized that Heantos-4 would suppress burst-firing in this neuronal class. VB neurons can display tonic-firing or rebound burst-firing upon depolarization or hyperpolarization from their resting membrane potential, respectively $[9,18]$. If the resting membrane potential is in range wherein the population of T-type calcium channels are balanced in the inactivated and closed states, a LTS can also occur via depolarization (as shown in Fig. 3a). For the purposes of this study we examined only rebound bursts since not all VB neurons displayed depolarizing bursts.

Current clamp recordings were performed on VB neurons using an acute brain slice preparation (Fig. 3). Rebound burst-firing threshold ( $\geq 3$ action potentials in $50 \mathrm{~ms}$ ) was determined by applying incremental current injection steps from the resting membrane potential (Fig. 3a). Heantos- 4 had little effect on current required to generate rebound burst-firing at concentrations at or below $0.1 \mathrm{mg} /$ $\mathrm{ml}$ (not shown). However, at $1 \mathrm{mg} / \mathrm{ml}$ Heantos-4 induced a significant increase the burst threshold (baseline $=-34 \pm 9.3$ pA, Heantos- $4=-176 \pm 56.6 \mathrm{pA}, P<0.05$ paired T-test; Fig. 3a and b) which was not observed in control (aCSF applied) neurons (baseline $=-58 \pm 17.0$, control $=-66 \pm 19.6$; $P>0.05$, paired T-test). This equated to a significant $\%$ increase in burst threshold in Heantos- 4 treated neurons compared to control (control $=17.3 \pm 17.6 \%$, Heantos $-4=$ $504.7 \pm 136.2 \%, P<0.05$ T-test). Heantos- 4 also induced a modest but significant depolarization of the resting 

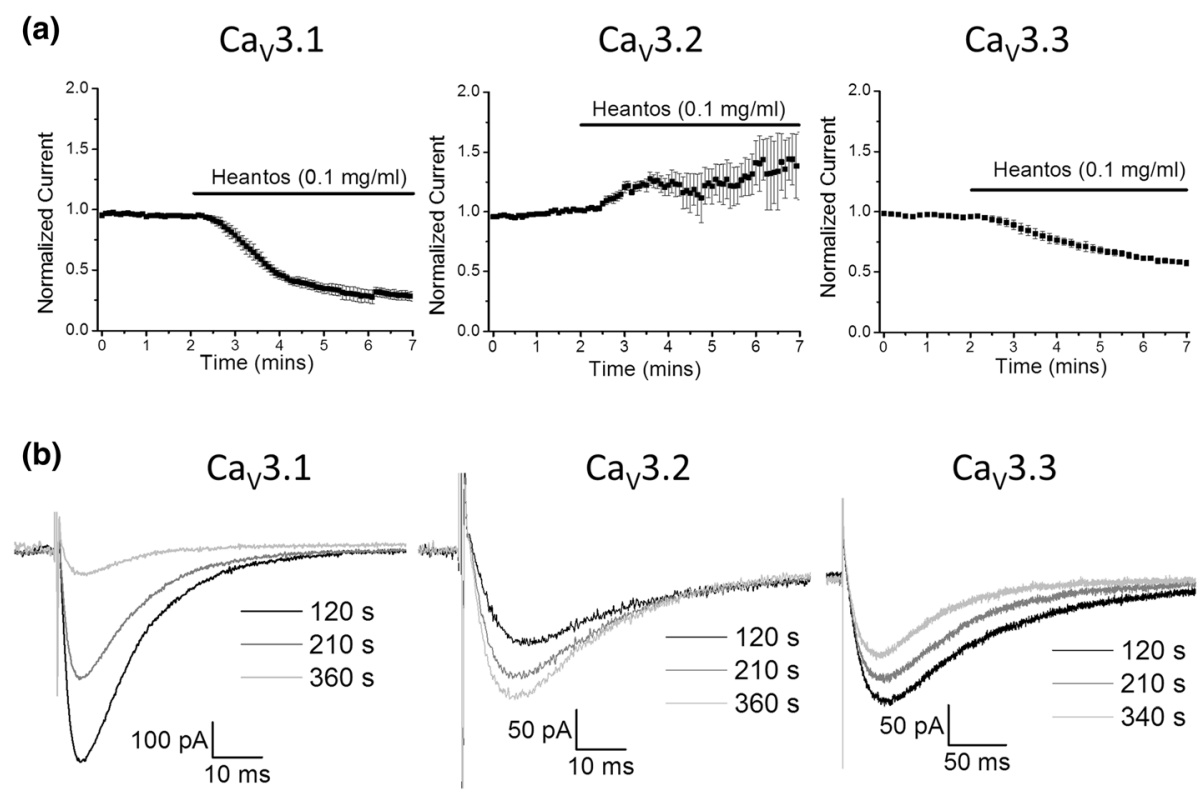

(c)

\section{$\mathrm{Ca}_{\mathrm{v}} 3.1$}

$\mathrm{Ca}_{\mathrm{v}} 3.2$

$\mathrm{Ca}_{\mathrm{v}} 3.3$
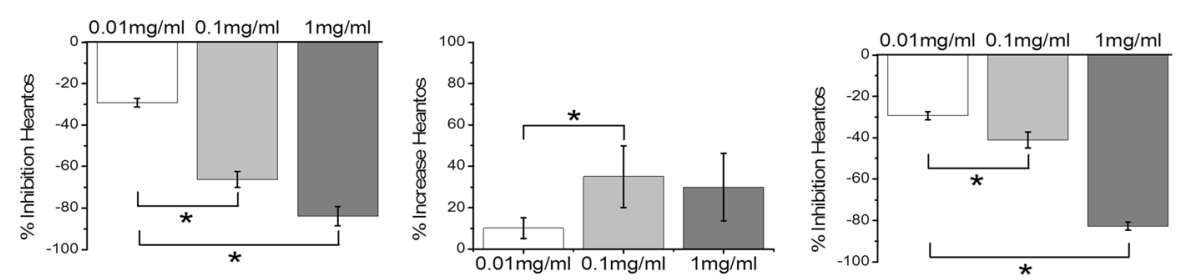

Fig. 1 Heantos differentially modulates current density of T-type calcium channel isoforms. a Timecourse of action of Heantos ( $0.1 \mathrm{mg} / \mathrm{ml})$ on individual T-type calcium channel isoforms ( $n=5$ per T-type isoform) exogenously expressed in HEK293 cells. b Representative traces of Cav3.1, Cav3.2 and Cav3.3 T-type calcium currents before and after Heantos application. c Histograms summarizing concentration-dependent action of Heantos on individual T-type calcium channel isoforms

membrane potential (baseline $=-72.2 \pm 1.0 \mathrm{mV}$, Heantos $=$ $-67.2 \pm 1.8 \mathrm{mV} ; P<0.05$, paired T-test, Fig. $3 \mathrm{c}$ ), that was not observed in control neurons (baseline $=-72.3 \pm 2.3$, control $=-71.7 \pm 1.8 ; P>0.05$, paired T-test). Heantos-4 had no effect on the number of action potentials per burst (Fig. 3d) or on the input resistance of VB neurons (Fig. 3e).

\section{Heantos-4 does not affect burst-firing in TRN neurons}

While VB neurons primarily express $\mathrm{Ca}_{\mathrm{V}} 3.1$ channels, the GABAergic TRN neurons that project to VB neurons express a combination of $\mathrm{Ca}_{\mathrm{V}} 3.2$ and $\mathrm{Ca}_{\mathrm{V}} 3.3$ [15, 17, 19]. Since Heantos- 4 potentiates $\mathrm{Ca}_{\mathrm{v}} 3.2$ but inhibits $\mathrm{Ca}_{\mathrm{v}} 3.3$ (Figs. 1 and 2) either a modest inhibition/potentiation or no effect could be hypothesized depending upon the relative co-expression of $\mathrm{Ca}_{\mathrm{v}} 3.2$ and $\mathrm{Ca}_{\mathrm{v}} 3.3$ in TRN neurons. The resting membrane potential of TRN neurons is hyperpolarized in comparison to VB neurons and as a result these neurons burst-fire in response to depolarization, but not hyperpolarization under normal conditions (Fig. 4a).
Current clamp recordings were performed on TRN neurons under the same conditions as described for $\mathrm{VB}$ neurons. At a concentration of $1 \mathrm{mg} / \mathrm{ml}$ Heantos- 4 had no effect on TRN burst-firing threshold or number of action potentials per burst. Similarly, no effect was observed on resting membrane potential or input resistance. A higher concentration of $5 \mathrm{mg} / \mathrm{ml}$ Heantos was also tested on TRN neurons. No significant effects were seen on burst firing or passive membrane properties at the $5 \mathrm{mg} / \mathrm{ml}$ Heantos concentration (Fig. 4b-e).

\section{Heantos- 4 exacerbates absence seizures in GAERS}

Burst-firing has been observed in key epileptogenic neurons in a number of animal epilepsy models [12,13]. The GAERS absence model displays spontaneous $5-9 \mathrm{~Hz}$ Spike-Wave Discharges (SWDs), the electroencephalographic correlate of absence seizures, from a juvenile age that intensify with development $[20,21]$ and burst-firing in GAERS TRN neurons occurs in a phase-locked manner with SWDs [22]. While a polygenic etiology is believed to underlie seizures in 
(a)

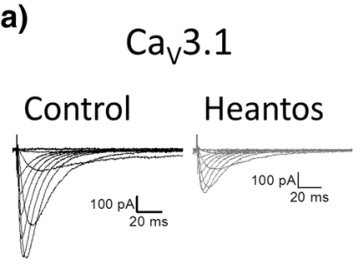

(b)

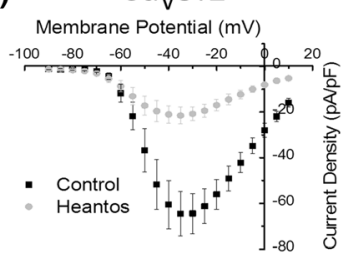

(c)
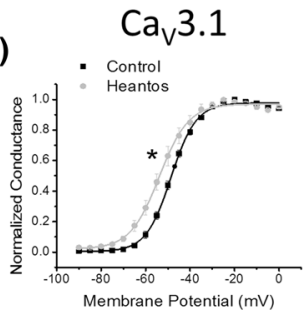

(d)

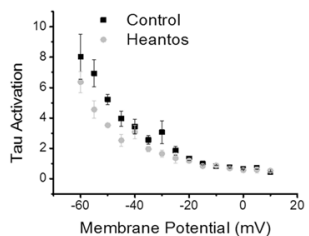

(e)

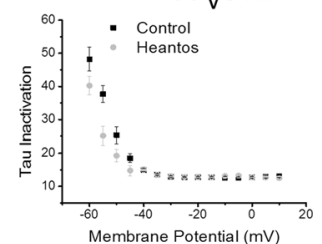

$\mathrm{Ca}_{\mathrm{V}} 3.2$

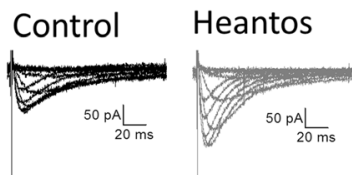

$\mathrm{Ca}_{\mathrm{V}} 3.2$

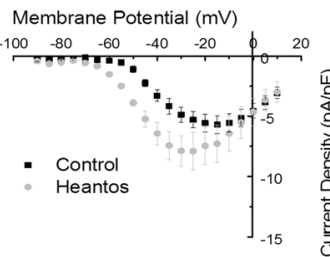

$\mathrm{Ca}_{\mathrm{V}} 3.2$

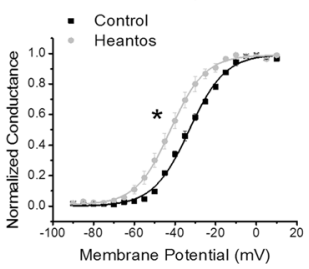

$\mathrm{Ca}_{\mathrm{v}} 3.2$

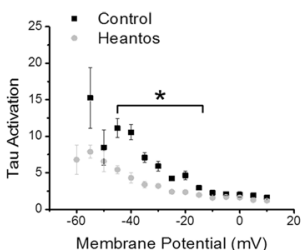

$\mathrm{Ca}_{\mathrm{v}} 3.2$

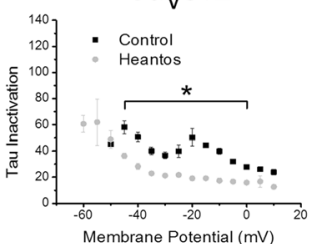

$\mathrm{Ca}_{\mathrm{V}} 3.3$

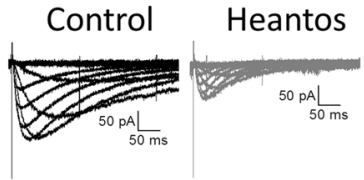

$\mathrm{Ca}_{\mathrm{V}} 3.3$

Membrane Potential ( $\mathrm{mV})$

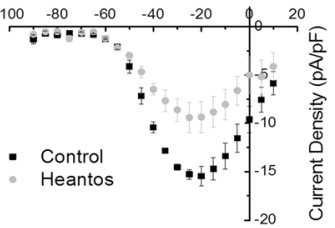

$\mathrm{Ca}_{\mathrm{v}} 3.3$

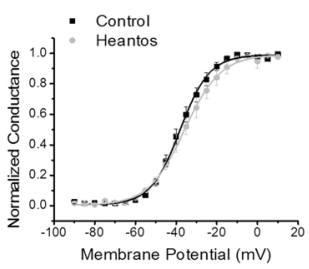

$\mathrm{Ca}_{\vee} 3.3$

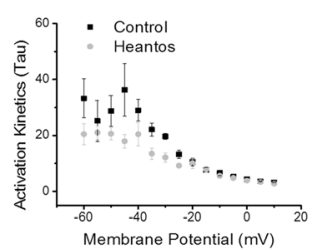

$\mathrm{Ca}_{\mathrm{v}} 3.3$

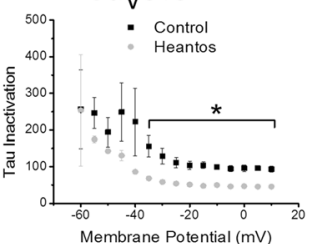

Fig. 2 Voltage-dependent effects of Heantos of T-type calcium channel isoforms. a Representative current traces to various test potentials from a holding potential of $-110 \mathrm{mV}$ before (black) and after (grey) Heantos $(0.1 \mathrm{mg} / \mathrm{ml})$. b Current density-voltage relationship, c voltage dependence of activation, $\mathbf{d}$ activation kinetics and $\mathbf{e}$ inactivation kinetics for the effect of Heantos $(0.1 \mathrm{mg} / \mathrm{ml})$ on Cav3.1, Cav3.2 and Cav3.3 T-type calcium channel currents ( $n=5$ per isoform)

this model, approximately $65-75 \%$ of the epileptic phenotype can be attributed to a gain-of-function missense mutation in the domain III-IV linker of the Cav 3.2 channel gene [23]. Within the thalamocortical network that drives absence seizures $\mathrm{Ca}_{\mathrm{V}} 3.2$ channels are expressed both in layer $\mathrm{V}$ of the cortex and in TRN neurons,[15] and $\mathrm{Ca}_{\mathrm{V}} 3.2$ channels are upregulated in the GAERS model [24, 25]. As such, it is likely that seizures in this model are caused by hyperexcitable cortico-reticular burst-firing.

Heantos-4 in its dry powdered form suspended in $\mathrm{CMC} /$ saline (see Methods) was orally administered to
GAERS rats 30 min prior to wireless EEG recording and data acquisition for $60 \mathrm{~min}$. Spontaneous seizures occurred throughout the recording period (Fig. 5). Heantos-4 had no effect on any of the seizure parameters measured at the $250 \mathrm{mg} / \mathrm{kg}$ dose compared to control animals. However, at a dose of $500 \mathrm{mg} / \mathrm{kg}$ there was a significant increase in seizure duration (control $=12.3 \pm 0.9 \mathrm{~s}$ $(n=5), 250 \mathrm{mg} / \mathrm{kg}=12.0 \pm 1.4 \mathrm{~s}(n=3), 500 \mathrm{mg} / \mathrm{kg}=18.6$ $\pm 2.3 \mathrm{~s}(n=3)$; control vs $250 \mathrm{mg} / \mathrm{kg} P=0.986$, control vs $500 \mathrm{mg} / \mathrm{kg} P=0.004,250 \mathrm{mg} / \mathrm{kg}$ vs $500 \mathrm{mg} / \mathrm{kg} P=$ 0.011 ANOVA); Fig. 5c). We also observed a variable 

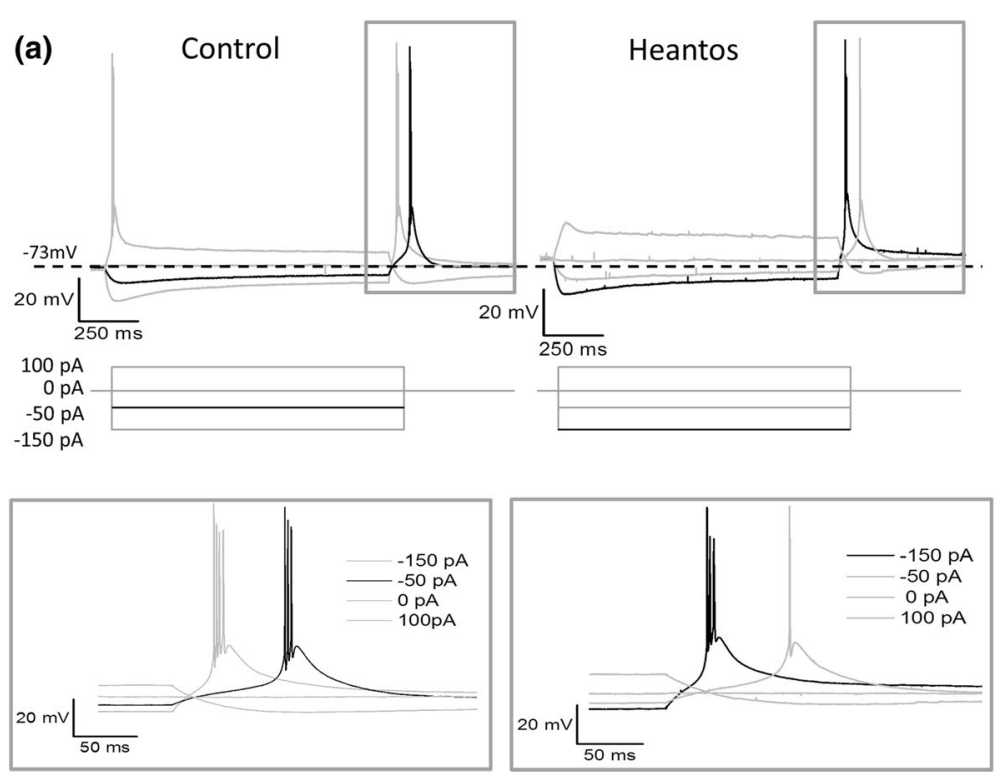

(b)

(c)
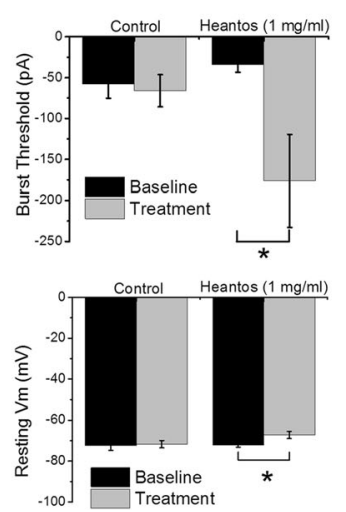

(d)

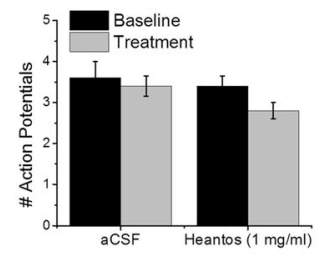

(e)

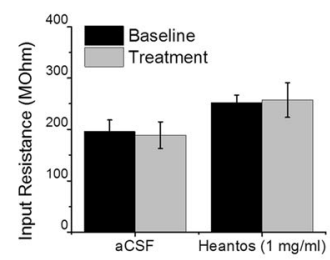

Fig. 3 Heantos inhibits burst firing in VB thalamic neurons. a Representative voltage traces showing input-output response of the same VB thalamic neuron before (left) and after (right) application of Heantos ( $1 \mathrm{mg} / \mathrm{ml})$. Lower panels show current injection protocol. Black traces show the threshold burst voltage and corresponding current injection. The same voltage traces are displayed at a higher time resolution of the region delineated by grey box for clarity. b Histograms summarizing mean burst threshold and $\mathbf{c}$ resting membrane potential before and after Heantos (1 mg/ml) or control (aCSF). $\mathbf{d}$ Histograms summarizing mean number of action potentials per burst and $\mathbf{e}$ input resistance for VB thalamic neurons before and after a 5 min application of aCSF $(n=5)$ or Heantos $(1 \mathrm{mg} / \mathrm{ml}(n=5))$

albeit non-significant increase in the \% time spent in the seizure state and in the number of seizures following $500 \mathrm{mg} / \mathrm{kg}$ Heantos-4 administration (Fig. 5b, d). Conversely, the spike frequency associated with seizures was unaffected by Heantos-4 at either dose (Fig. 5e). Together these findings indicate that at high doses of oral administration Heantos-4 may exacerbate seizure activity in animals with a predisposal to cortico-reticular seizures. Mechanistically in GAERS this could occur as a result of enhancing the gain-of-function alteration in $\mathrm{Ca}_{V} 3.2$ channels within the cortical seizure initiation focus.

\section{Discussion}

Heantos-4 is approved by the Vietnamese Food and Drug Administration and is used clinically to treat opiate addicts in Vietnam [4], although has not yet received formal approval for use in Western addiction treatment programs. During periods of Heantos- 4 treatment, patients report not only a reduction in withdrawal symptoms and possibly craving, but also strong sedative effects. While studies are ongoing in an effort to decipher its mechanism of action with respect to drug-seeking behaviour and neurotransmitter release [5], we sought to examine its effects on burst-firing in the thalamus due to the role of this region in the control of arousal [26, 27]. We first established that Heantos inhibits $\mathrm{Ca}_{\mathrm{V}} 3.1$ and $\mathrm{Ca}_{\mathrm{V}} 3.3$ but potentiates $\mathrm{Ca}_{\mathrm{v}} 3.2$ channels, and subsequently found that burst-firing was differentially modulated in two distinct classes of thalamic neurons. In VB neurons that primarily express $\mathrm{Ca}_{\mathrm{V}} 3.1$ burst firing was inhibited by Heantos, but in TRN neurons that express a combination of $\mathrm{Ca}_{\mathrm{v}} 3.2$ and $\mathrm{Ca}_{\mathrm{V}} 3.3$ burst-firing was not affected. 

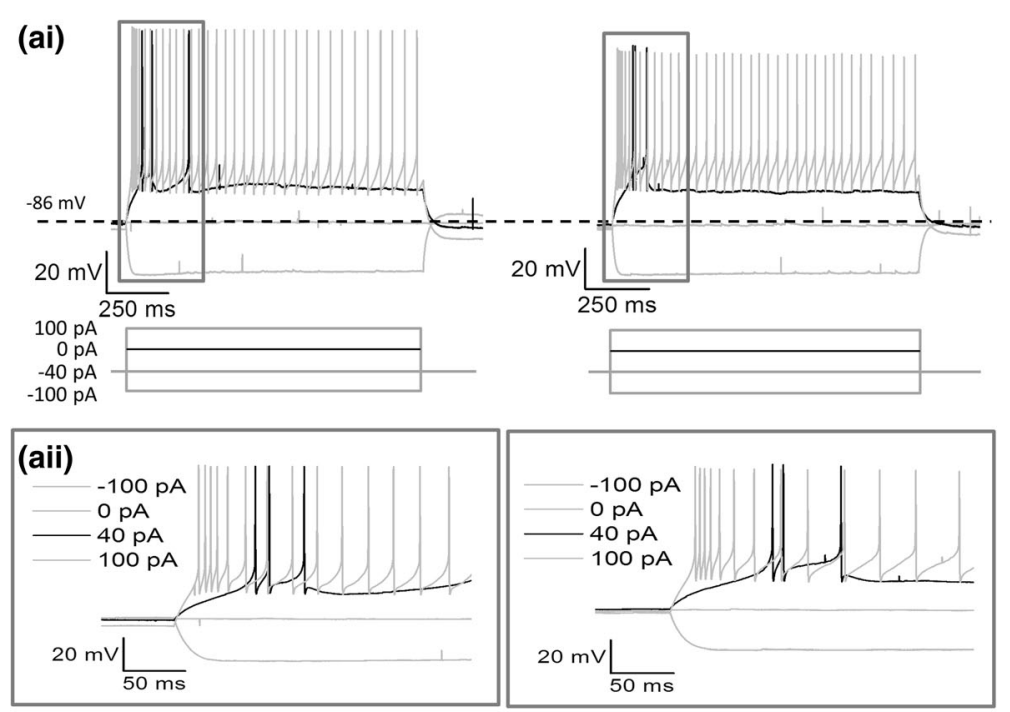

(b)

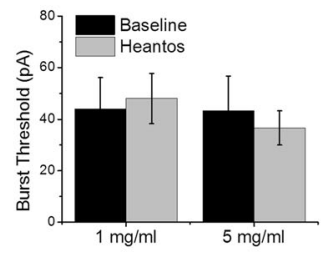

(c)

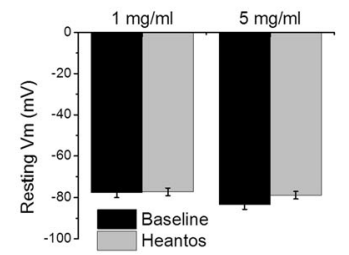

(d)

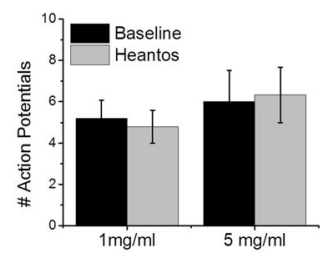

(e)

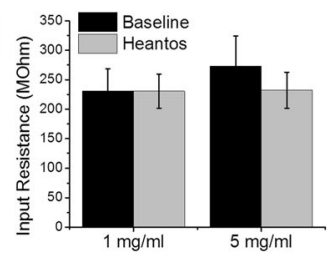

Fig. 4 Heantos does not affect burst firing in TRN neurons. a Representative voltage traces showing input-output response of the same TRN thalamic neuron before (left) and after (right) application of Heantos $(1 \mathrm{mg} / \mathrm{ml}, 5 \mathrm{mg} / \mathrm{ml})$. Lower panels show current injection protocol. Black traces show the threshold burst voltage and corresponding current injection. The same voltage traces are displayed at a higher time resolution of the region delineated by grey box for clarity. b Histograms summarizing mean current injection for burst threshold, c resting membrane potential, $\mathbf{d}$ number of action potentials and e mean input resistance for TRN thalamic neurons before and after a $5 \mathrm{~min}$ application of Heantos $(1 \mathrm{mg} / \mathrm{ml}(n=5), 5 \mathrm{mg} / \mathrm{ml}(n=3))$

\section{Differential modulation of T-type calcium channel isoforms}

To date only a few pharmacological agents have been discovered that can selectively distinguish between the three distinct T-type calcium channel isoforms. $\mathrm{Ca}_{\mathrm{V}} 3.2$ channels display a degree of redox sensitivity due to the presence of extracellular cysteine residues and/or a histidine residue found only in $\mathrm{Ca}_{\mathrm{v}} 3.2$, but not $\mathrm{Ca}_{\mathrm{v}} 3.1$ or Cav 3.3 channels $[19,28,29]$. As a result $\mathrm{Ca}_{\mathrm{V}} 3.2$ channels are inhibited by oxidation and potentiated by reduction of at least one of these residues. In addition, $\mathrm{Ca}_{\mathrm{V}} 3.2$ displays a higher efficacy to inhibition by nickel $(<100 \mu \mathrm{M})$ and other trace metals due to the presence of a high affinity binding and metal-catalyzed oxidation site provided by the same extracellular histidine residue [30]. Heantos- 4 is a mixture of 12 organic herbs $[4,5]$ and the potentiation of $\mathrm{Ca}_{\mathrm{v}} 3.2$ could occur as a result of one or more active components. Of note, a shift in the activation curve to hyperpolarized potentials is observed in $\mathrm{Ca}_{\mathrm{v}} 3.1$ and $\mathrm{Ca}_{\mathrm{v}} 3.2$ channels, but not in $\mathrm{Ca}_{\mathrm{v}} 3.3$ channels. Redox modulation of $\mathrm{Ca}_{\mathrm{v}} 3.2$ channels induces only nominal effects on the voltage-dependence of activation [29]. However, reduction of recombinant $\mathrm{Ca}_{\mathrm{v}} 3.2$ channels with L-cysteine has been reported to cause an approximate $5 \mathrm{mV}$ shift towards hyperpolarized potentials [19]. This is in agreement with Heantos-mediated potentiation of $\mathrm{Ca}_{\mathrm{v}} 3.2$ currents via reduction of redoxsensitive channel residues. However, the mechanism underlying the Heantos-mediated differential modulation of voltage-dependence of activation in $\mathrm{Ca}_{\mathrm{v}} 3.1$ and $\mathrm{Ca}_{\mathrm{V}} 3.3$ channels is unknown. It is possible that Heantos contains certain components that inhibit both $\mathrm{Ca}_{\mathrm{V}} 3.1$ 


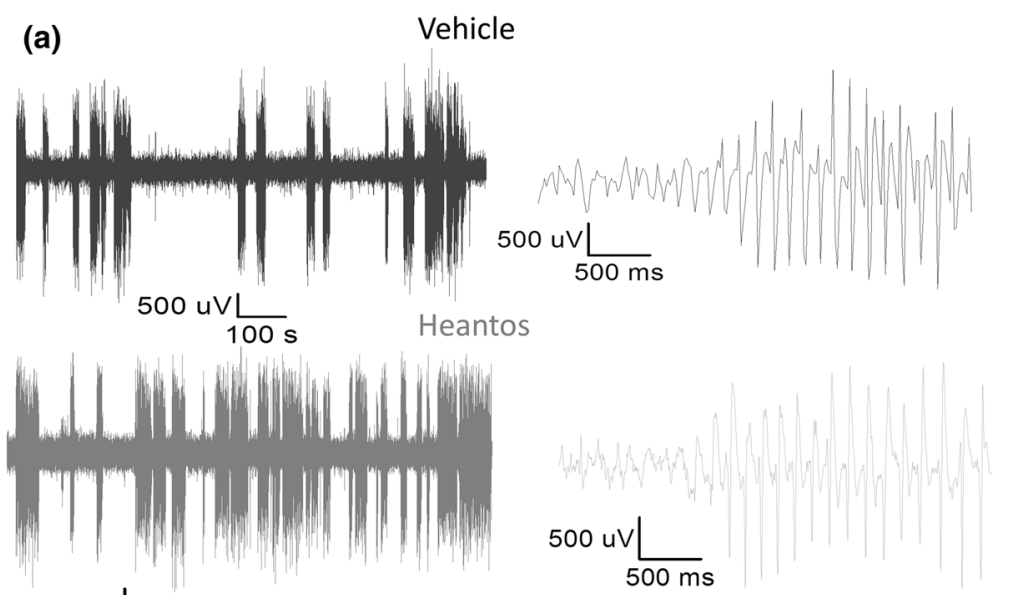

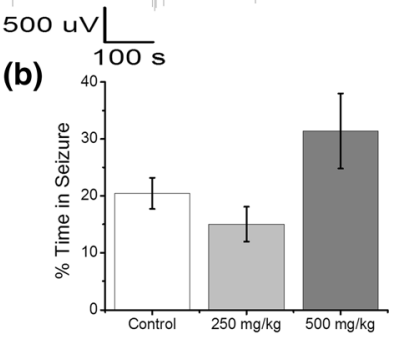

(d)

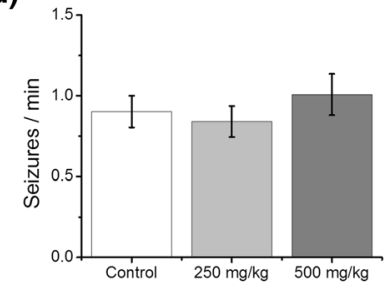

(c)

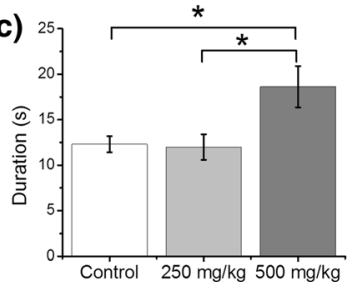

(e)

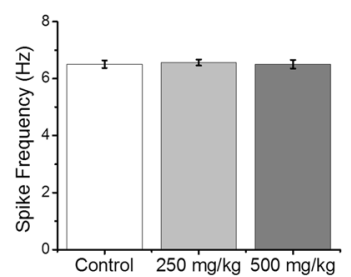

Fig. 5 Heantos exacerbates seizures in the GAERS model. a Representative EEG traces from GAERS orally administered with control (0.5\% CMC; upper traces) or Heantos (500 mg/kg; lower traces) at low (left trace) and high (right traces) time resolution. Histograms displaying mean data for b \% time spent in seizure state, c seizure duration, $\mathbf{d}$ number of seizures and e spike frequency

and $\mathrm{Ca}_{\mathrm{v}} 3.3$, and other components that modulate the gating dynamics of Cav3.1 only. Alternately, a single component of Heantos may have a differential effect on the gating of $\mathrm{Ca}_{\mathrm{v}} 3.1$ and $\mathrm{Ca}_{\mathrm{v}} 3.3$, while simultaneously inhibiting both channels. Once analysis of the active components in Heantos has been performed it will be possible to dissect out how this differential modulation occurs. Further research is required to determine the exact compound(s) that induce the potentiation of $\mathrm{Ca}_{\mathrm{V}} 3.2$ and also the inhibition of $\mathrm{Ca}_{\mathrm{V}} 3.1$ and $\mathrm{Ca}_{\mathrm{V}} 3.3$. To this end, we are currently conducting mass spectrographic analyses of Heantos- 4 compounds that pass into the cerebrospinal fluid compartment in vivo. Preliminary analyses confirm the presence in brain CSF of $>98 \%$ of phytochemical classes identified with the components of Heantos-4 (data not shown). In the meanwhile, given that existing T-type channel pharmacological tools are limited to the redox-mediated inhibition or potentiation of $\mathrm{Ca}_{\mathrm{V}} 3.2$ without affecting $\mathrm{Ca}_{\mathrm{v}} 3.1$ or $\mathrm{Ca}_{\mathrm{V}} 3.3$, Heantos-4 provides a novel pharmacological tool to inhibit $\mathrm{Ca}_{\mathrm{V}} 3.1$ or $\mathrm{Ca}_{\mathrm{v}} 3.3$ and potentiate $\mathrm{Ca}_{\mathrm{v}} 3.2$.

\section{Selective inhibition of VB thalamic neurons}

Agents that block all three T-type channel isoforms abolish both depolarizing burst-firing in TRN neurons and rebound burst-firing in thalamocortical neurons $[18,31-34]$. Of note, to date no pharmacological agents have been identified that can selectively inhibit burst-firing in thalamocortical neurons without also inhibiting TRN neurons.

The T-type calcium currents that underlie lowthreshold burst-firing in thalamic neurons have been studied extensively (for review see $[8,14]$ ). In thalamocortical neurons the relatively fast and short burst duration supports a role of $\mathrm{Ca}_{\mathrm{V}} 3.1$ due to its fast activation/inactivation kinetics and hyperpolarized voltage-dependence of activation [35]. This is further supported by analysis of T-type calcium channel mRNA expression using both 
in situ hybridization [15] and quantitative PCR [17, 36]. In addition, genetic ablation of the Cacnalg gene that encodes $\mathrm{Ca}_{\mathrm{v}} 3.1$ in mice abolishes burst-firing in thalamocortical neurons [16].

In TRN neurons the burst duration activates quickly but is of longer duration than in VB neurons indicating that the combined $\mathrm{Ca}_{\mathrm{v}} 3.2 / \mathrm{Ca}_{\mathrm{v}} 3.3$ currents underlie the LTS since $\mathrm{Ca}_{\mathrm{V}} 3.2$ channels activate quickly and $\mathrm{Ca}_{\mathrm{V}} 3.3$ channels inactivate slowly $[8,37]$. This notion is supported by mRNA analyses [15] and by redox pharmacological evidence. As discussed, $\mathrm{Ca}_{\mathrm{V}} 3.2$ is redox sensitive and TRN neurons display enhanced or suppressed burst-firing upon application of reducing and oxidizing agents, respectively [19]. In support, T-type currents in TRN neurons can be potentiated up to $50 \%$ by reducing agents and inhibited up to $50 \%$ by oxidizing agents. Further, in mice following genetic ablation of the Cacnali gene, encoding $\mathrm{Ca}_{\mathrm{V}} 3.3$ the T-type current is approximately $40 \%$ of the total T-type current in TRN neurons of wild-type mice [38]. In a separate study investigating a strain of mice lacking the $\mathrm{Ca}_{\mathrm{v}} 3.3$ channel, T-type calcium currents were attenuated by approximately $80 \%$ in comparison to wild-type mice, although low threshold bursts could still be elicited in $75 \%$ of animals [39]. Of note, the remaining T-type calcium current is absent and burst-firing abolished in double $\mathrm{Ca}_{\mathrm{V}} 3.2 / \mathrm{Ca}_{\mathrm{V}} 3.3$ knockout mice [39]. Taken together $\mathrm{Ca}_{\mathrm{V}} 3.2$ currents are predicted to contribute $20-40 \%$ of the total T-type calcium channel current in TRN neurons, with the remaining current contributed by the $\mathrm{Ca}_{\mathrm{V}} 3.3$ isoform. This assumption is supported by our finding that Heantos-4 has no effect on burst-firing in TRN neurons and agrees with our in vitro data showing potentiation of $\mathrm{Ca}_{\mathrm{v}} 3.2$ and inhibition of $\mathrm{Cav}_{\mathrm{v}} 3.3$ currents and predicted to result in opposing modulation that cancels out any global effect on the total T-type current.

\section{Heantos and T-type calcium channel blockade in addic- tion and neurological disorders}

To date, Heantos- 4 has been used clinically solely for the purpose of treating aspects of drug addiction. The paraventricular thalamic nucleus (PVN) has been implicated in drug-seeking behaviour [40] and T-type calcium channel activity has been identified in midline PVN neurons [41, 42]. While $\mathrm{Ca}_{\mathrm{v}} 3.1 \mathrm{mRNA}$ is expressed at higher levels in burst-firing PVN neurons than the other T-type channel isoforms, the PVN LTS is abolished by $50 \mu \mathrm{M}$ nickel implicating $\mathrm{Ca}_{\mathrm{V}} 3.2$ since this concentration would not block $\mathrm{Ca}_{\mathrm{v}} 3.1$ currents [43]. Further, $\mathrm{Ca}_{\mathrm{v}} 3.2$, not $\mathrm{Ca}_{\mathrm{v}} 3.1$ appears to be involved in pain transduction in the PVN [44]. With further relevance to addiction, TTA-A2, a pan T-type calcium channel blocker attenuates food- versus nicotine-induced cue-potentiated reinstatement for a response previously reinforced by food administration in rats [45]. This suggests that T-type antagonists have the potential to alleviate nicotine addiction. Although limited, these studies provide support for a direct role of T-type calcium channels in the acquisition and/or maintenance of addiction.

In addition to addiction, T-type calcium channels are implicated in a number of other neurological disorders including in epileptic seizures [12-14, 46-48], anxiety [49-51], cognitive and memory impairments $[52,53]$, and in the transmission of pain [54-57]. Pan T-type blockers that block burst-firing in both VB [18] and TRN [31] neurons have been shown to suppress seizures in animal models of absence epilepsy [31,58], prevent seizure kindling in a model of complex-partial seizures [59], and suppress tonicclonic seizures [60]. In terms of pain signalling, pan T-type antagonists have shown efficacy in reducing pain sensation in both animal models [54,61-63] and humans [64, 65]. T-type calcium currents underlying burst-firing and slow oscillations in the thalamocortical system have been extensively linked to non-REM sleep [6]. Somewhat counterintuitively, pan-T-type calcium channel antagonists have been shown to induce sedation [66, 67] rather than the awake state, perhaps indicating that the T-type calcium channel subtypes individually mediate distinct roles within the thalamocortical system and that block of all three subtypes shifts equilibrium to the sleep state. Taken together, Heantos-4 may have potential as a subtypespecific T-type calcium channel antagonist for use as both a pharmacological tool and potential therapeutic agent.

In summary, Heantos-4 is a clinically utilized treatment for drug addiction and is currently the subject of studies aimed at determining its mechanism(s) of action [5]. Here we show that Heantos-4 selectively inhibits $\mathrm{Ca}_{2} 3.1$ and $\mathrm{Ca}_{\mathrm{V}} 3.3$ but potentiates $\mathrm{Ca}_{\mathrm{v}} 3.2$ T-type calcium currents. In addition, Heantos-4 selectively inhibits burst-firing in VB thalamic neurons while having no significant effect on TRN neurons. This supports the data from exogenously expressed T-type calcium channel isoforms and their corresponding differential expression in distinct VB and TRN thalamic nuclei. That Heantos-4 appears to exacerbate absence seizure activity in GAERS suggest that caution may be warranted in the clinical usage of Heantos-4 in seizure-prone individuals. Determining whether the effect of Heantos-4 on T-type calcium channels is related to its role in the treatment of drug-craving and withdrawal will require additional studies. Regardless, our findings that Heantos-4 differentially modulates distinct neuronal populations expressing T-type calcium channel isoforms may be relevant with respect to a number of neurological disorders in which T-type calcium channels are implicated $[13,68]$. 


\section{Methods}

\section{Electrophysiology on exogenously expressed T-type} calcium channel isoforms

Flp-In 293 cells (Invitrogen), stably expressing pcDNA5/ FRT plasmids containing $\mathrm{hCa}_{\mathrm{V}} 3.1, \mathrm{hCa}_{\mathrm{V}} 3.2$ or $\mathrm{hCa}_{\mathrm{V}} 3.3$ were grown at $37{ }^{\circ} \mathrm{C}$ in DMEM supplemented with $10 \%$ heat inactivated fetal bovine serum. Cells expressing Ttype calcium channel isoforms were selected by incubation with hygromycin. Cells were seeded on poly-D-Lysine $(0.1 \mathrm{mg} / \mathrm{ml})$ coated glass coverslips and hygromycin removed from media $48 \mathrm{~h}$ before voltage clamp recordings.

Calcium currents were recorded at $22-24{ }^{\circ} \mathrm{C}$ using whole-cell voltage clamp with the following solutions containing in mM: Internal: 120 Cs-Methanesulphonate, 11 EGTA, 10 HEPES, $2 \mathrm{MgCl}_{2}$, $5 \mathrm{MgATP}$ and $0.3 \mathrm{NaGTP}$ (pH 7.2) External: $2 \mathrm{CaCl}_{2}, 1 \mathrm{MgCl}_{2}, 10 \mathrm{HEPES}, 40$ TEACl, $92 \mathrm{CsCl}$ and 10 Glucose $(\mathrm{pH} \mathrm{7.4)}$. Fire polished patch pipettes (borosilicate glass) had typical resistances of 3 to $5 \mathrm{M} \Omega$ when containing internal solution. The recording chamber was grounded with a $\mathrm{Ag} / \mathrm{AgCl}$ pellet. Whole-cell currents were recorded at room temperature using an Axopatch 200B amplifier (Axon instruments Inc., Union City, CA). Data was acquired with pClamp software package version 9 (Axon Instruments Inc.). Series resistance (Rs) was compensated by $65-75 \%$ and seals with Rs values higher than $20 \mathrm{M} \Omega$ or cells with peak current lower than 100pA were discarded. Currents sampled at $10 \mathrm{kHz}$ and filtered at $2 \mathrm{kHz}$. Data analysis was carried out using Clampfit 9 (Axon Instruments Inc.) and software Origin version 7.5 (OriginLab Corp., Northampton, MA).

Timecourse of drug action was obtained by depolarizing the membrane with a $200 \mathrm{msec}$ pulse to $-30 \mathrm{mV}$ from a holding potential of $-100 \mathrm{mV}$ every $5 \mathrm{~s}$. The peak calcium current was taken from each trace for analysis. A two minute stable baseline was acquired before initiating a five minute Heantos application via the perfusate.

The current-voltage (I-V) relationship was obtained before and after the timecourse protocol by depolarizing the membrane with pulses $\left(\mathrm{Ca}_{\mathrm{V}} 3.1\right.$ and $\mathrm{Ca}_{\mathrm{V}} 3.2=150 \mathrm{msec}$, $\mathrm{Ca}_{\mathrm{V}} 3.3=450 \mathrm{msec}$ ) from a holding potential of $-110 \mathrm{mV}$. Test pulses from -90 to $+10 \mathrm{mV}$ were applied at $5 \mathrm{mV}$ steps. Peak amplitude of calcium currents was plotted against test pulse potential and I-V curves were fitted using a modified Boltzmann equation: $\mathrm{I}=\left(\mathrm{Gmax}^{*}(\mathrm{Vm}-\right.$ $\mathrm{Er})) /(1+\exp ((\mathrm{Vm}-\mathrm{V} 50) / \mathrm{k}))$, where Gmax is the maximum value of membrane conductance, $\mathrm{Vm}$ is the test potential, Er is the extrapolated reversal potential, V50 is the half-activation potential, and $\mathrm{k}$ (Slope constant: $\mathrm{k}=\mathrm{RT} / \mathrm{z} \delta \mathrm{F}$; where $\mathrm{R}=$ gas constant, $\mathrm{T}=$ absolute temperature, $\mathrm{z}=$ valence of conducting ion, $\delta$ =electrical distance across the membrane, $\mathrm{F}=$ Faraday's constant) reflects the voltage sensitivity. Activation curves were obtained by calculating conductance from the I-V curves and plotting the normalized conductance as a function of the membrane potential. The data was fitted with the Boltzmann equation: $\mathrm{G} / \mathrm{Gmax}=\mathrm{A} 2+(\mathrm{A} 1-\mathrm{A} 2) /(1+\exp ((\mathrm{Vm}-\mathrm{V} 50) / \mathrm{k}))$, where $\mathrm{A} 1$ is minimum normalized conductance, A2 is maximum normalized conductance, $\mathrm{Vm}$ is the test potential, $V_{50}$ is the half-activation potential, and $k$ value the slope of the activation curve (Slope constant).

\section{Acute brain slice electrophysiology}

Male and female Wistar rats (P15-P20) were used in acute brain slice experiments in accordance with Canadian Council for Animal Care guidelines.

Animals were anesthetized using isoflurane $\left(5 \%\right.$ in $\left.\mathrm{O}_{2}\right)$, sacrificed by decapitation, the brains rapidly removed and transferred to ice cold sucrose-aCSF containing in mM: 214 sucrose, $26 \mathrm{NaHCO}_{3}, 1.25 \mathrm{NaH}_{2} \mathrm{PO}_{4}, 11$ glucose, $2.5 \mathrm{KCl}, 0.5 \mathrm{CaCl}_{2}, 6 \mathrm{MgCl}_{2}$, bubbled with $95 \%$ $\mathrm{O}_{2}: 5 \% \mathrm{CO}_{2}$. Brain tissue was glued to a cutting chamber in a vibrating microtome (VT 1200, Leica, USA), which was then filled with ice cold sucrose-aCSF. Horizontal brain slices containing the whole thalamus $(350 \mu \mathrm{m}$ thick) were cut from the level of the ventral TRN/VB and incubated for a minimum of $30 \mathrm{~min}$ at $34{ }^{\circ} \mathrm{C}$ in a current clamp recording solution containing in $\mathrm{mM}: 126$ $\mathrm{NaCl}, 2.5 \mathrm{KCl}, 26 \mathrm{NaHCO}_{3}, 1.5 \mathrm{NaH}_{2} \mathrm{PO} 4,2 \mathrm{CaCl}_{2}, 2$ $\mathrm{MgCl}_{2}, 10$ glucose; bubbled with $95 \% \mathrm{O}_{2}: 5 \% \mathrm{CO}_{2}$. Slices were transferred to a recording chamber superfused with current clamp recording solution and maintained at $33-35{ }^{\circ} \mathrm{C}$. VB and TRN neurons were visualized using a DIC microscope (Axioskop 2-FS Plus, Carl Zeiss) and infrared camera (IR-1000, DAGE MTI) and visually identified by their location, morphology and orientation. All recordings were undertaken using a Multiclamp 700B amplifier and pClamp software version 9 (Molecular devices). The recording chamber was grounded with a $\mathrm{Ag} / \mathrm{AgCl}$ pellet.

Whole cell current clamp recordings were undertaken using fire polished borosilicate glass pipettes (4-6 M $\Omega$ ) filled with the following solution containing in $\mathrm{mM}$ : 120 K-gluconate, $10 \mathrm{HEPES}, 1 \mathrm{MgCl}_{2}, 1 \mathrm{CaCl}_{2}, 11 \mathrm{KCl}$, 11 EGTA, 4 MgATP, 0.5 NaGTP , pH adjusted to 7.2 using $\mathrm{KOH}$, osmolarity adjusted to $290 \mathrm{mOsm} / \mathrm{kg}$ using D-mannitol. The liquid junction potential for current clamp solutions was calculated as $+13.3 \mathrm{mV}$ and corrected off-line. To evaluate input-output neuronal responses to hyperpolarization and depolarization, DC current was injected from $-100 \mathrm{pA}$ to $+200 \mathrm{pA}$ in $10 \mathrm{pA}$ increments for a duration of $1200 \mathrm{~ms}$ at the neuron's intrinsic resting membrane potential. VB neurons that did not rebound burst fire with $\leq-100 \mathrm{pA}$ current injection were then evaluated with a current injection protocol where DC current was injected from $-100 \mathrm{pA}$ to -500 pA in 50 pA increments. Membrane potential responses under current clamp conditions were sampled at $50 \mathrm{kHz}$ 
and filtered at $10 \mathrm{kHz}$. Bridge balance was monitored during recordings and any neurons displaying bridge balance values greater than $25 \mathrm{M} \Omega$ were discarded. Capacitance neutralization was performed between 3.8 and $4.2 \mathrm{pF}$.

\section{EEG recording}

Adult GAERS (4-6 month old) were anesthetized with isoflurane and implanted with skull screw electrodes on the somatosensory cortex surface (bregma $=+1.2 \mathrm{~mm}$, lateral $= \pm 5.0 \mathrm{~mm}$, depth below skull $=0.1 \mathrm{~mm}$ ) and a reference electrode in the cerebellum (lambda $=-0.5$ $\mathrm{mm}$, lateral $=-0.5 \mathrm{~mm}$, depth below skull $=1 \mathrm{~mm}$ ). Electrodes were connected to a custom EEG interface implanted on the skull. Following a 2 week recovery period the interface was connected to a wireless headstage (W2100, Multichannel Systems, Germany) and EEG signals acquired in the animals' home cage for $1 \mathrm{~h}$.

\section{Drugs}

Heantos-4, a brown, tea-like powder was provided by Dr. Sung at the Institute of Chemistry, Vietnam Academy of Science and Technology (Hanoi, Vietnam). For in vitro electrophysiology experiments Heantos-4 was prepared at $1 \mathrm{mg} / \mathrm{ml}$ by immersing in aCSF, vortexing for several seconds and incubating at $50{ }^{\circ} \mathrm{C}$ for $10 \mathrm{~min}$ followed by sonication at $22-24{ }^{\circ} \mathrm{C}$ for $5 \mathrm{~min}$. Insoluble components of Heantos were then filtered and the flow-through used in all experiments at this concentration $(1 \mathrm{mg} / \mathrm{ml})$ or as a serial dilution.

For in vivo experiments Heantos- 4 was mixed into $0.5 \%$ carboxymethylcellulose (CMC) in $0.9 \%$ saline and administered via oral gavage $30 \mathrm{~min}$ prior to $\mathrm{EEG}$ recording.

\section{Statistics}

Data followed a normal distribution and statistical significance was calculated using Student's T-test (paired where appropriate) or ANOVA with Tukey's Post-hoc test taking $P$ value $<0.05$ as significant. Data was plotted as mean values \pm standard error.

\section{Abbreviations}

Cav: Voltage-gated calcium channel; GAERS: Genetic Absence Epilepsy Rats from Strasbourg; HVA: High Voltage-Activated; LTS: Low Threshold calcium Spike; SWDs: Spike-Wave Discharges; TRN: Reticular thalamic nucleus; VB: Ventrobasal thalamic nucleus

\section{Acknowledgements}

Not Applicable.

\section{Funding}

T.P. Snutch is supported by an operating grant from the Canadian Institutes of Health Research (\#10677) and the Canada Research Chair in

Biotechnology and Genomics-Neurobiology. S.M. Cain is supported by a research grant from the B.C. Epilepsy Society. A.G. Phillips is supported by an operating grant from the Canadian Institutes of Health Research (\#101025).

\section{Availability of data and materials}

All data generated or analysed during this study are included in this published article.

\section{Authors' contributions}

SMC undertook in vitro and in vivo electrophysiological experiments, participated in study design and coordination and drafted the manuscript. SA performed in vivo EEG experiments and edited the manuscript. EG, YZ and ZW performed in vitro exogenous electrophysiology experiments. JY generated Cav clones. YY performed EEG implantation. TVS provided Heantos-4. AGP participated in study design and coordination and edited the manuscript. TPS participated in study design and coordination and drafted the manuscript. All authors read and approved the final manuscript.

\section{Competing interests}

Dr. T.V. Sung is a director of Heantos.jsc and a beneficial owner of shares in this company.

\section{Consent for publication}

Not applicable.

\section{Ethics approval}

All animal procedures were undertaken in accordance with Canadian Council on Animal Care guidelines.

\section{Author details}

${ }^{1}$ Michael Smith Laboratories and Djavad Mowafaghian Centre for Brain Health, University of British Columbia, 219-2185 East Mall, Vancouver, BC V6T 1Z4, Canada. ${ }^{2}$ Department of Psychiatry, University of British Columbia, Vancouver, Canada. ${ }^{3}$ Institute of Chemistry, Vietnam Academy of Science and Technology, Hanoi, Vietnam.

Received: 29 September 2016 Accepted: 21 November 2016 Published online: 05 December 2016

\section{References}

1. WHO | Information sheet on opioid overdose. WHO. http://www.who.int/ substance_abuse/information-sheet/en/.

2. Bell J. Pharmacological maintenance treatments of opiate addiction. $\mathrm{Br} \mathrm{J}$ Clin Pharmacol. 2014;77:253-63.

3. Bart G. Maintenance medication for opiate addiction: the foundation of recovery. J Addict Dis. 2012;31:207-25.

4. Aldhous P. Drug rehabilitation: cold turkey, Vietnamese style. Nature. 2005:433:568-9.

5. Dias C, Ahn S, Ma B, Sung TV, Phillips AG. Behavioural and Neurochemical Assessment of Heantos 4 on Preclinical Models of Morphine-Dependence. J Addict Res Ther. 2016;7(4). doi: 10.4172/2155-6105.1000292.

6. Crunelli V, Cope DW, Hughes SW. Thalamic T-type Ca2+ channels and NREM sleep. Cell Calcium. 2006:40:175-90.

7. Catterall WA. Voltage-gated calcium channels. Cold Spring Harb Perspect Biol. 2011;3:a003947.

8. Cain SM, Snutch TP. Contributions of T-type calcium channel isoforms to neuronal firing. Channels. 2010;4:44-51.

9. Huguenard JR. Low-threshold calcium currents in central nervous system neurons. Annu Rev Physiol. 1996;58:329-48.

10. Sherman SM. Tonic and burst firing: dual modes of thalamocortical relay. Trends Neurosci. 2001;24:122-6.

11. Contreras D. The role of T-channels in the generation of thalamocortical rhythms. CNS Neurol Disord Drug Targets. 2006;5:571-85.

12. Noebels $\mathrm{JL}$. The Voltage-Gated Calcium Channel and Absence Epilepsy. In: Noebels JL, Avoli M, Rogawski MA, Olsen RW, Delgado-Escueta AV, editors. Jaspers Basic Mech. Epilepsies. 4th ed. Bethesda (MD): National Center for Biotechnology Information (US); 2012.

13. Cain SM, Snutch TP. Voltage-gated calcium channels in epilepsy. In: Noebels JL, Avoli M, Rogawski MA, Olsen RW, Delgado-Escueta A, editors. Jaspers Basic Mech. Epilepsies. 4th ed. Bethesda: Oxford University Press; 2012. p. 66-84.

14. Cain SM, Snutch TP. T-type calcium channels in burst-firing, network synchrony, and epilepsy. Biochim Biophys Acta. 1828;2012:1572-8.

15. Talley EM, Cribbs LL, Lee JH, Daud A, Perez-Reyes E, Bayliss DA. Differential distribution of three members of a gene family encoding low voltageactivated (T-type) calcium channels. J Neurosci. 1999;19:1895-911.

16. Kim D, Song I, Keum S, Lee T, Jeong MJ, Kim SS, et al. Lack of the burst firing of thalamocortical relay neurons and resistance to absence seizures in mice lacking alpha(1G) T-type Ca2+ channels. Neuron. 2001;31:35-45. 
17. Broicher T, Kanyshkova T, Meuth P, Pape HC, Budde T. Correlation of Tchannel coding gene expression, IT, and the low threshold Ca2+ spike in the thalamus of a rat model of absence epilepsy. Mol Cell Neurosci. 2008;39:384-99.

18. Cain SM, Tyson JR, Jones KL, Snutch TP. Thalamocortical neurons display suppressed burst-firing due to an enhanced Ih current in a genetic model of absence epilepsy. Pflüg Arch Eur J Physiol. 2015;467:1367-82.

19. Joksovic PM, Nelson MT, Jevtovic-Todorovic V, Patel MK, Perez-Reyes E, Campbell KP, et al. CaV3.2 is the major molecular substrate for redox regulation of T-type $\mathrm{Ca} 2+$ channels in the rat and mouse thalamus. J Physiol. 2006;574:415-30.

20. Danober L, Deransart C, Depaulis A, Vergnes M, Marescaux C. Pathophysiological mechanisms of genetic absence epilepsy in the rat. Prog Neurobiol. 1998;55:27-57

21. Marescaux C, Vergnes M, Depaulis A. Genetic absence epilepsy in rats from Strasbourg-a review. J Neural Transm Suppl. 1992;35:37-69.

22. Slaght SJ, Leresche N, Deniau JM, Crunelli V, Charpier S. Activity of thalamic reticular neurons during spontaneous genetically determined spike and wave discharges. J Neurosci. 2002;22:2323-34.

23. Powell KL, Cain SM, Ng C, Sirdesai S, David LS, Kyi M, et al. A Cav3.2 T-type calcium channel point mutation has splice-variant-specific effects on function and segregates with seizure expression in a polygenic rat model of absence epilepsy. J Neurosci. 2009;29:371-80.

24. Tsakiridou E, Bertollini $L$, de Curtis M, Avanzini G, Pape HC. Selective increase in T-type calcium conductance of reticular thalamic neurons in a rat model of absence epilepsy. J Neurosci. 1995;15:3110-7.

25. Talley EM, Solorzano G, Depaulis A, Perez-Reyes E, Bayliss DA. Low-voltageactivated calcium channel subunit expression in a genetic model of absence epilepsy in the rat. Brain Res Mol Brain Res. 2000;75:159-65.

26. Schiff ND. Central thalamic contributions to arousal regulation and neurological disorders of consciousness. Ann N Y Acad Sci. 2008;1129:105-18.

27. Brown RE, Basheer R, McKenna JT, Strecker RE, McCarley RW. Control of sleep and wakefulness. Physiol Rev. 2012;92:1087-187.

28. Lee J, Nelson MT, Rose KE, Todorovic SM. Redox mechanism of Snitrosothiol modulation of neuronal CaV3.2 T-type calcium channels. Mol. Neurobiol. 2013;48:274-80.

29. Nelson MT, Joksovic PM, Su P, Kang HW, Van Deusen A, Baumgart JP, et al. Molecular mechanisms of subtype-specific inhibition of neuronal T-type calcium channels by ascorbate. J Neurosci. 2007;27:12577-83.

30. Kang H-W, Park J-Y, Jeong S-W, Kim J-A, Moon H-J, Perez-Reyes E, et al. A molecular determinant of nickel inhibition in Cav3.2 T-type calcium channels. J Biol Chem. 2006:281:4823-30.

31. Tringham E, Powell KL, Cain SM, Kuplast K, Mezeyova J, Weerapura M, et al. T-type calcium channel blockers that attenuate thalamic burst firing and suppress absence seizures. Sci Transl Med. 2012;4:121ra19.

32. Dreyfus FM, Tscherter A, Errington AC, Renger JJ, Shin HS, Uebele VN, et al. Selective T-type calcium channel block in thalamic neurons reveals channel redundancy and physiological impact of I(T)window. J Neurosci. 2010;30:99-109.

33. Errington $A C$, Renger JJ, Uebele VN, Crunelli V. State-dependent firing determines intrinsic dendritic Ca2+ signaling in thalamocortical neurons. J Neurosci. 2010;30:14843-53.

34. Eckle V-S, Digruccio MR, Uebele VN, Renger JJ, Todorovic SM. Inhibition of T-type calcium current in rat thalamocortical neurons by isoflurane. Neuropharmacology. 2012;63:266-73.

35. Coulter DA, Huguenard JR, Prince DA. Calcium currents in rat thalamocortical relay neurones: kinetic properties of the transient, lowthreshold current. J Physiol. 1989;414:587-604.

36. Broicher T, Kanyshkova T, Landgraf P, Rankovic V, Meuth P, Meuth SG, et al. Specific expression of low-voltage-activated calcium channel isoforms and splice variants in thalamic local circuit interneurons. Mol Cell Neurosci. 2007;36:132-45.

37. Huguenard JR, Prince DA. A novel T-type current underlies prolonged $\mathrm{Ca}(2+)$-dependent burst firing in GABAergic neurons of rat thalamic reticular nucleus. J Neurosci. 1992;12:3804-17.

38. Astori S, Wimmer RD, Prosser HM, Corti C, Corsi M, Liaudet N, et al. The $\mathrm{Ca}(\mathrm{V}) 3.3$ calcium channel is the major sleep spindle pacemaker in thalamus. Proc Natl Acad Sci U S A. 2011;108:13823-8.

39. Lee SE, Lee J, Latchoumane C, Lee B, Oh S-J, Saud ZA, et al. Rebound burst firing in the reticular thalamus is not essential for pharmacological absence seizures in mice. Proc Natl Acad Sci. 2014;111:11828-33.
40. Matzeu A, Zamora-Martinez ER, Martin-Fardon R. The paraventricular nucleus of the thalamus is recruited by both natural rewards and drugs of abuse: recent evidence of a pivotal role for orexin/hypocretin signaling in this thalamic nucleus in drug-seeking behavior. Front Behav Neurosci. 2014:8:117.

41. Zhang L, Renaud LP, Kolaj M. Properties of a T-type Ca2 + channel-activated slow afterhyperpolarization in thalamic paraventricular nucleus and other thalamic midline neurons. J Neurophysiol. 2009;101:2741-50.

42. Kolaj M, Zhang L, Hermes MLHJ, Renaud LP. Intrinsic properties and neuropharmacology of midline paraventricular thalamic nucleus neurons. Front Behav Neurosci. 2014:8:132.

43. Lee S, Han TH, Sonner PM, Stern JE, Ryu PD, Lee SY. Molecular characterization of T-type $\mathrm{Ca}(2+)$ channels responsible for low threshold spikes in hypothalamic paraventricular nucleus neurons. Neuroscience. 2008;155:1195-203.

44. Chen W-K, Liu IY, Chang Y-T, Chen Y-C, Chen C-C, Yen C-T, et al. Ca(v)3.2 T-type Ca2+ channel-dependent activation of ERK in paraventricular thalamus modulates acid-induced chronic muscle pain. J Neurosci Off J Soc Neurosci. 2010:30:10360-8.

45. Uslaner JM, Vardigan JD, Drott JM, Uebele VN, Renger JJ, Lee A, et al. T-type calcium channel antagonism decreases motivation for nicotine and blocks nicotine- and cue-induced reinstatement for a response previously reinforced with nicotine. Biol Psychiatry. 2010;68:712-8.

46. Huguenard JR. Neuronal circuitry of thalamocortical epilepsy and mechanisms of antiabsence drug action. Adv Neurol. 1999;79:991-9.

47. Crunelli V, Leresche N. Childhood absence epilepsy: genes, channels, neurons and networks. Nat Rev Neurosci. 2002;3:371-82.

48. Powell KL, Cain SM, Snutch TP, O'Brien TJ. Low threshold T-type calcium channels as targets for novel epilepsy treatments. Br J Clin. Pharmacol. 2014; 77:729-39.

49. Gangarossa G, Laffray S, Bourinet E, Valjent E. T-type calcium channel Cav3.2 deficient mice show elevated anxiety, impaired memory and reduced sensitivity to psychostimulants. Front Behav Neurosci. 2014;8:92.

50. Munro G, Erichsen HK, Mirza NR. Pharmacological comparison of anticonvulsant drugs in animal models of persistent pain and anxiety. Neuropharmacology. 2007:53:609-18.

51. Marks WN, Cavanagh ME, Greba Q, Cain SM, Snutch TP, Howland JG. The Genetic Absence Epilepsy Rats from Strasbourg model of absence epilepsy exhibits alterations in fear conditioning and latent inhibition consistent with psychiatric comorbidities in humans. Eur J Neurosci. 2016;43:25-40.

52. Marks WN, Greba Q, Cain SM, Snutch TP, Howland JG. The T-type calcium channel antagonist Z944 disrupts prepulse inhibition in both epileptic and non-epileptic rats. Neuroscience. 2016;332:121-9.

53. Marks WN, Cain SM, Snutch TP, Howland JG. The T-type calcium channel antagonist Z944 rescues impairments in crossmodal and visual recognition memory in Genetic Absence Epilepsy Rats from Strasbourg. Neurobiol Dis. 2016:94:106-15.

54. François A, Laffray S, Pizzoccaro A, Eschalier A, Bourinet E. T-type calcium channels in chronic pain: mouse models and specific blockers. Pflüg Arch Eur J Physiol. 2014;466:707-17.

55. Todorovic SM, Jevtovic-Todorovic V. Targeting of CaV3.2 T-type calcium channels in peripheral sensory neurons for the treatment of painful diabetic neuropathy. Pflügers Arch Eur J Physiol. 2014:466:701-6.

56. Pexton T, Moeller-Bertram T, Schilling JM, Wallace MS. Targeting voltagegated calcium channels for the treatment of neuropathic pain: a review of drug development. Expert Opin Investig Drugs. 2011;20:1277-84.

57. Zamponi GW, Lewis RJ, Todorovic SM, Arneric SP, Snutch TP. Role of voltage-gated calcium channels in ascending pain pathways. Brain Res Rev. 2009;60:84-9.

58. Uebele VN, Nuss CE, Fox SV, Garson SL, Cristescu R, Doran SM, et al. Positive allosteric interaction of structurally diverse T-type calcium channel antagonists. Cell Biochem Biophys. 2009:55:81-93.

59. Casillas-Espinosa PM, Hicks A, Jeffreys A, Snutch TP, O'Brien TJ, Powell KL. Z944, a Novel Selective T-Type Calcium Channel Antagonist Delays the Progression of Seizures in the Amygdala Kindling Model. PloS One. 2015. Epub. doi: 10.1371/journal.pone.0130012.

60. Sakkaki S, Gangarossa G, Lerat B, Françon D, Forichon L, Chemin J, et al. Blockade of T-type calcium channels prevents tonic-clonic seizures in a maximal electroshock seizure model. Neuropharmacology. 2016;101:320-9.

61. LeBlanc BW, Lii TR, Huang JJ, Chao Y-C, Bowary PM, Cross BS, et al. T-type calcium channel blocker Z944 restores cortical synchrony and 
thalamocortical connectivity in a rat model of neuropathic pain. Pain. 2016;157:255-63.

62. Samour MS, Nagi SS, Mahns DA. Cav3.2-expressing low-threshold C fibres in human hairy skin contribute to cold allodynia-a non-TRPV1- and non-

TRPM8-dependent phenomenon. Pain. 2015;156:1566-75.

63. Choe W, Messinger RB, Leach E, Eckle V-S, Obradovic A, Salajegheh R, et al. TTA-P2 is a potent and selective blocker of T-type calcium channels in rat sensory neurons and a novel antinociceptive agent. Mol Pharmacol. 2011; 80:900-10.

64. Lee M. Z944: A first in class T-type calcium channel modulator for the treatment of pain. J Peripher Nerv Syst. 2014;19:S11-2.

65. Nagi SS, Dunn JS, Birznieks I, Vickery RM, Mahns DA. The effects of preferential A- and C-fibre blocks and T-type calcium channel antagonist on detection of low-force monofilaments in healthy human participants. BMC Neurosci. 2015;16:52

66. Yang Z-Q, Schlegel K-AS, Shu Y, Reger TS, Cube R, Mattern C, et al. Shortacting T-type calcium channel antagonists significantly modify sleep architecture in rodents. ACS Med Chem Lett. 2010;1:504-9.

67. Kraus RL, Li Y, Gregan Y, Gotter AL, Uebele VN, Fox SV, et al. In vitro characterization of T-type calcium channel antagonist TTA-A2 and in vivo effects on arousal in mice. J Pharmacol Exp Ther. 2010;335:409-17.

68. Cain SM, Snutch TP. Voltage-gated calcium channels and disease. BioFactors Oxf Engl. 2011;37:197-205.

\section{Submit your next manuscript to BioMed Central} and we will help you at every step:

- We accept pre-submission inquiries

- Our selector tool helps you to find the most relevant journal

- We provide round the clock customer support

- Convenient online submission

- Thorough peer review

- Inclusion in PubMed and all major indexing services

- Maximum visibility for your research

Submit your manuscript at www.biomedcentral.com/submit 